April 2013

\title{
Critical Conversations: Developing White Teachers for Diverse Classrooms
}

Omobolade O. Delano-Oriaran Ph.D

St. Norbert College, De Pere, WI, bola.delano-oriaran@snc.edu

Tynisha D. Meidl Ph.D

St. Norbert College, De Pere, WI, tynisha.meidl@snc.edu

Follow this and additional works at: https://digitalscholarship.unlv.edu/jpme

\section{Repository Citation}

Delano-Oriaran, Omobolade O. Ph.D and Meidl, Tynisha D. Ph.D (2013) "Critical Conversations: Developing White Teachers for Diverse Classrooms," Journal of Praxis in Multicultural Education: Vol. 7: No. 1, Article 1.

DOI: 10.9741/2161-2978.1042

Available at: https://digitalscholarship.unlv.edu/jpme/vol7/iss1/1

This Article is protected by copyright and/or related rights. It has been brought to you by Digital Scholarship@UNLV with permission from the rights-holder(s). You are free to use this Article in any way that is permitted by the copyright and related rights legislation that applies to your use. For other uses you need to obtain permission from the rights-holder(s) directly, unless additional rights are indicated by a Creative Commons license in the record and/ or on the work itself.

This Article has been accepted for inclusion in Journal of Praxis in Multicultural Education by an authorized administrator of Digital Scholarship@UNLV. For more information, please contact digitalscholarship@unlv.edu. 
By 2030, half of the students attending American schools will be from culturally and linguistically diverse (CLD) backgrounds (Sadker, Sadker, \& Zittleman, 2008). This cultural mosaic within U.S. classrooms has spurred a growing concern with regard to meeting the needs of these students. Scholars have asserted that CLD students are alienated, invisible, disengaged within the classroom, dropping out of school early and at high rates, limited in exposure to rigorous curriculum, and experiencing low teacher quality and expectations (Cartledge \& Kourea, 2008; Delpit, 2006; Gay, 2000, 2003; Kozol, 2005; LadsonBillings, 1994; Manning, 2000; Nieto, 2000; Sleeter, 2001). In addition, they are learning within dilapidated physical conditions, encountering teacher unwillingness to accept the diversity of the United States, experiencing inappropriate assessment, and disproportionately placed within special education.

We have a teaching force that is culturally and linguistically different from the student population, with the majority of these educators being White and female (Chisholm, 1994; Monroe, 2005). Howard (2006) conducted an investigation of the optimal methods of meeting the needs of CLD students and posited, "The what and the how of multicultural teaching and learning [has been addressed] but we have not adequately addressed the why and the who" (p. 5). This study focuses on the "who"-White in-service teachers and their understanding of their own White racial identity. 
Several theorists have discussed the study of Whiteness and its impact on CLD students (Lawrence \& Tatum, 1998; Roman, 1993; Sleeter, 1993; Tatum, 1992). According to Solomon et al. (2005), such study "seeks to have teachers and teacher candidates examine their overall understanding of their racial identity, the ideologies with which they enter the classroom, and . . the impact of those ideologies on their teaching practices and their interactions with students" (p. 149). Hence the authors begin with an overview of White racial identity development theories and their impact on White in-service teachers, and share findings from a book-discussion professional development program. The need for White in-service teachers to examine their racial identity and to evaluate how this may impede or promote their ability to successfully meet the needs of CLD students is explored.

\section{Theoretical Framework}

Social constructionism inquiry guides research on racial identity development. It provides a process by which people tend to view themselves within a racially conscious world. Thus, many White racial identity development theories and models, among them Hardiman (1982, 1992), Helms (1984) and Ponterotto (1988), have been developed and proposed to explain how Whites respond to race and racism within their own environment. However, prior to these models, $\mathrm{Du}$ 
Bois in 1973 "urged Whites to turn their lens of analysis about race around and look at themselves in the mirror" (Hardiman, 2001, p. 108). We apply these socially constructed lenses as a theoretical framework to the various White identity development models and typologies and discuss their effect on White teachers in the classroom.

\section{Socially Constructed "Lens"}

Race is often a determining factor in gaining access to opportunities, status, power, and privilege. This social construct is a salient factor currently providing unearned privileges to White citizens. McIntosh (1988) described privilege as "an invisible weightless knapsack of special provisions, assurances, tools, maps, guides, codebooks, passports, visas, clothes, compasses, emergency gear, and blank checks" (pp. 1-2) "carried" by those of the White race, especially within the United States. Considering the value placed upon race, it is critical for White teachers to examine what it really means to be White and how this intersects with the identities they present to CLD students.

Many White teachers with no exposure to or opportunity to reflect upon the social constructs of Whiteness are socially unaware of its implications. Consequently, these educators typically are oblivious to racism; avoid racial and social issues; deny the social construction of race; and assume no responsibility 
for, nor take any action to reverse, the social implications of Whiteness (Hardiman, 1982; Helms, 1999; Hill-Jackson, 2007; Ponterotto, Utsey, \& Pedersen, 2006). Theorists have defined this mind-set as the contact (Helms, 1999) or preexposure (Ponterotto, 1988) schema, within which the social value or benefits of race are completely disregarded. Individuals within this mode "simply think of themselves as being part of the racial norm and take this for granted without conscious consideration of their White privilege" (Tatum, 1994, p. 94). They tend to be racist and to perpetuate White dominance and superiority (Howard, 2006). Teachers within this phase believe they have no culture; treat all students the same under a "mask" of "color blindness"; and claim, "I don't really see color, I just see children" (Ladson-Billings, 1994, p. 31) or "I am just American" (Howard, 2006, p. 103).

Educators experiencing the contact or preexposure schema feel and act by embracing Western-centric, assimilationist (Howard, 2006; Ladson-Billings, 1994) values and teaching from a Eurocentric pedagogy. According to LadsonBillings (1994), these teachers "do not really see the students at all and are limited in their ability to meet their educational needs" (p. 33). They are in a state of unconsciousness or dysconsciousness (Ladson-Billings, 1994) and, as Helms argued, are oblivious to, and/or deny, the social value of Whiteness (as cited in Hardiman, 2001). They tend to be ignorant of the privileges and benefits associated with racism (Howard, 2006). White individuals experiencing this 
schema may have contact with people of color, which subsequently initiates them into the racial development process (Howard, 2006).

As a means to understand the social construction of race, one must first recognize individuals as cultural beings. Therefore, everyone is influenced by microcultures, including but not limited to the following: race, gender, socioeconomic status, ethnicity, age, spirituality, language, sexual orientation, family unit, and geographic location (Tatum, 1992). However, we live in a racialized world and society where race has become a dominant factor because it is often manifested in physical characteristics that differentiate individuals. Considering the value placed on race, it is critical for White teachers to examine what it means to be White in society, and how their own understanding of Whiteness intersects with the personal and professional identities that they present to CLD students within school and classroom environments.

\section{Deconstructed Lens}

As educators begin to explore their biases and prejudices surrounding race and "students of color" (D’Angelo \& Dixey, 2001; Ford \& Trotman, 2001), reflection commonly ensues on what it means to be a cultural being and the role this plays in teaching CLD students, thus forcing the educators' current state of unconsciousness or dysconsciousness to "unravel." The unlearning process may 
be precipitated by exposure to issues of diversity (Ponterotto, 1988), such as engaging in conversation with people of color or attending race-related professional-development conferences. A measure of dissonance is often experienced on the learning continuum, involving a degree of racial discomfort, disequilibrium, and internal conflict (DiCaprio, n.d.; Sue et al., 1998). Many theorists have described the onset of developmental deconstruction as the conflict disintegration, reintegration, and responsiveness schema (Helms, 1999; HillJackson, 2007; LaFleur, Row, \& Leach, 2002; Rowe, Behrens, \& Leach, 1995; Rowe, Bennett, \& Atkinson, 1994; Sabnani, Ponterotto, \& Borodovsky, 1991). As educators continue to examine their cultural perceptions, conflicting emotions emerge between learned and newly introduced perspectives. White teachers are often caught between conforming to a Eurocentric, "mainstream" worldview where they "play into White norms" (Gorski, 1998, p. 11) and a yearning to engage in a multicultural view of the world. According to Helms, the latter view includes a desire to "advocate against discrimination and risk alienation from the White community" (as cited in Gorski, 1998, p. 11). Gallagher stated, "My first year of teaching sent me down the road of questioning my attitudes and childhood tapes about those different from me" (as cited in Howard, 2006, p. 93). Cultural dissonance is clearly evident and conflicted between two worlds. The first world is built upon a foundation of previously held racist beliefs, causing some to succumb to the social pressures of White 
ideologies or seek acceptance by the White majority. Feelings of anger toward people of color may exist here, along with a sense of alienation from the empowerment to challenge traditional mainstream norms.

The second world within which cultural dissonance is conflicted involves those of White ethnicity experiencing the issue of people of color being treated as inferior to those of the White dominant group (Ponterotto et al., 2006; Sabnani et al., 1991; Sue et al., 1998). Their exposure to new knowledge challenges them to reflect upon what it means to be White within an oppressive society. With this "kaleidoscope" of emotions, White people may choose to separate themselves from those of color, while others may encourage their White counterparts to deconstruct negative norms and stereotypes by convincing their "White friends that people of color aren't really as bad" (Howard, 2006, p. 94) as they have been taught. Individuals experiencing this dichotomous relationship may develop interests and curiosity surrounding the many experiences of people of color and, as Helms underscored, become fearful with regard to the related realities (as cited in Ponterotto et al., 2006). Individuals are abandoning previously held racist identities and merging into new, racially conscious White identities, perhaps choosing to either develop or affirm cross-racial relationships.

\section{Reconstructed Lens}


Once the unlearning process has occurred, White individuals have reconstructed and relearned a new awareness, consciousness, and tolerance, as opposed to mere acceptance. Actualization of their social status and privilege as White people has manifested and, as the new White identity emerges, an academic understanding of racial classification (Sneed, Schwartz, \& Cross, 2006) and/or of race as a system of advantage (Tatum, 1997) has developed, yet, with uncertainty as to its use. Their new "skin" is still fragile. They will not support active racism, nor will they recognize its institutionalized form. Tatum (1997) identified this individual as the "guilty White liberal" (p. 106). The need or urge to address social ills and issues faced by people of color becomes a dominant quality for White individuals experiencing reconstruction. Consequently, they make every attempt to relinquish any negative feelings surrounding Whiteness (Howard, 2006).

White educators within the described phase of reconstructed identity begin to search for antiracist allies. They resist racism and the role of the oppressor and actively work toward social change. They trust and support the lived realities of people of color and are open to any feedback or critique from this population (Gardiner, 2009; Tatum, 1997). Some individuals may feel marginalized (Marshall, 2002) as a result of a lack of success with finding allies in the work against social injustice, while others may find success in this effort and hence feel embraced, empowered, and rejuvenated as a result of interaction with those experiencing the same type of journey (Ponterotto et al., 2006). Tatum (1997) 
emphasized the critical need for the participation of Whites in an all-White group of allies, because this provides a safe space for honest dialogue to sort through any feelings of guilt and/or shame. As Ponterotto succinctly explained, "Frankly, people of color don't necessarily want to hear about it" (p. 111). Populations of color are aware of the racist, oppressive nature of American society, and the responsibility of the ally is not to remind those oppressed of the harsh realities while "walking the talk."

\section{Transformationist Lens}

At the final developmental schema, White individuals have transformed into a new personal and professional racial identity within which they are comfortable. They acknowledge and reject the hierarchal structure of Whiteness and its social implications. They reject notions that "suggest skin color privileges are owed to White people" (Marshall, 2002, p. 11). Such individuals actively seek authentic cross-cultural relationships free of bias or prejudice (Diller \& Moule, 2005) and become actively involved in efforts to eliminate racism and other forms of oppression on both micro and macro levels (Howard, 2006; Marshall, 2002; Ponterotto et al., 2006). They use their privilege to advance equity and justice, advocate by speaking out against the oppressive nature of American society 
(Tatum, 1997), and avoid scenarios involving racial oppression (Helms, 1995; Ponterotto et al., 2006).

Teachers that use the transformationist lens have cultivated the ability to successfully teach students with cultural backgrounds different from their own (Diller \& Moule, 2005). They have reflected upon and acknowledged their racial biases and stereotypes (Ford \& Trotman, 2001) and understand their influence in their teaching and relationships with CLD students. These educators employ multicultural education, culturally relevant and culturally responsive approaches and pedagogy (Banks, 2002; Gay, 2000; Grant \& Sleeter, 2007; Ladson-Billings, 1994). When transformationist teachers implement multicultural curricular approaches, they change the very structure of the curriculum and teach within and across all content areas to enable students to view issues from a multicultural perspective. They provide equal education opportunities for all students, build upon the background and experiences of CLD students, empower students to think critically, leave no child academically behind, and teach equality, justice, and power (Banks, 2002; Gay, 2003; Grant \& Sleeter, 2007).

Deconstructing, reconstructing, and transforming White teachers' racial identity are critical in meeting the needs of CLD students. This process lays the foundation for White educators to become racially and culturally conscious, culturally competent, responsive, and multiculturally aware in the classroom in order to bridge the cultural gap (Grant \& Sleeter, 2007). Identity formation and 
understanding one's identity is defined as a process or as a reflective journey involving the process of unlearning and relearning, which hopefully culminates in the personal and professional transformation White teachers need to experience in order to successfully meet the needs of CLD students.

\section{Purpose of the Research}

Many interrelated factors have been identified to fix and reform conditions in our nations' public schools and to respond to the needs and status of CLD students. Paramount to all of this is bridging the gap to address the cultural mismatch evident in our schools (Howard, 2006; Delpit, 2006; Ford \& Trotman, 2001). As issues of race and diversity continue to be integral to the success of CLD students, this exploratory study is meant to qualitatively document the ways White teachers understand their own racial identity and the role it plays in the success of their students. The purpose of this research was twofold: (1) to examine how teachers make sense of their own racial identity, and (2) to determine whether a professional development program can impact teachers' pedagogy and teaching in racially diverse classrooms. Nevertheless, understanding one's racialized identity and the role it plays in a classroom with CLD students will lead to attaining the knowledge, skills, and disposition needed to create an inclusive classroom environment for all learners. 


\section{Methods}

A qualitative content analysis was employed for this investigation. The study was guided by the following research questions (Creswell, 1998): Can structured discussion facilitate the understanding of the social construction of Whiteness for in-service teachers? Can a book discussion challenge in-service teachers to critically think about their role in meeting the needs of CLD students? Consistent with qualitative data-analysis approaches, the data collected were coded. Data analysis draws upon participant responses and research field notes. As a result, the initial research questions were revised to form the following two, more focused research questions:

1. How can group book discussion be used to facilitate understanding of the social construction of Whiteness by in-service teachers?

2. How will group book discussion, as a professional-development approach, challenge teachers to think critically about their role in meeting the needs of CLD students?

The data for this study were collected as part of a multicultural awareness project specifically designed for PK-12 in-service teachers, which included a series of focused group book discussions. The project was organized by a community multicultural center in conjunction with a teacher-education program 
at a nearby college and supported by area school districts. The districts were asked to invite educators to participate in this voluntary book-discussion professional development opportunity.

\section{Participants}

A sample of 15 participants was initially planned; however, 36 educators volunteered. Eight later declined due to time constraints or adverse views surrounding the book selection. Two discussion groups were created due to the high response rate. The majority of the participants were elementary and secondary teachers from four school districts.

\section{Materials}

Participants were notified about the project goal of engaging in critical conversations on race, racism, and racial identity and their implications for CLD students. Two books were recommended for discussion, and participating educators were offered the choice of which they perceived as meeting their needs. Gary Howard's (2006) We Can't Teach What We Don't Know: White Teachers, Multiracial Schools was selected as the preferred book by the project participants. 


\section{Procedures}

Participants met once per week for 2 hours over a 4-week period. The first meeting established the "ground rules" and prepared the participants for the topics that would emerge from the reading. The research employed a field log to organize and document data. Notes were documented by the facilitator using the modalities of cultural competency, as defined by Howard (2006), to frame the participants' responses. To triangulate the data, narrative reflections from the facilitator were used along with peer review of the data to confirm or question the findings as understood by the researcher. An open-ended evaluation administered to the participants at the culmination of the series served to strengthen reliability of the findings.

\section{Data Analysis}

Data analysis is the process of systematically searching and arranging accumulated data to increase personal understanding and to present what is discovered to others (Bogdan \& Bicklen, 1998). Thus, the role of the researcher is important to this study. The primary author served as the facilitator for the book discussion. The facilitator is also a person of color. It was important that the facilitator consistently reflect on personal bias as a means not to "taint" the 
data or the interpretation of the data. A limitation of this research is that the responses of the in-service teachers may have been influenced by their knowledge of the views of the primary author and experience with the text used in the study. For this reason, a "peer reviewer" was employed as a mean to confirm or disconfirm findings. The "peer reviewer" was not connected to the study and did not participate in the data collection process or the discussions (Merriam, 1998).

The research questions guided the process of data analysis, interpretation, and presentation of the conceptual framework for this study. Three sources of data were analyzed, both as single sources of data and for the relationships between them (Stake, 1995). The researcher searched for patterns of behavior and outcomes that generated a list of categories. After categories were identified, the data were manually coded to visually denote the patterns and the contradictions. Data analysis followed a recursive pattern of making constant comparisons across the data set in order to identify patterns and contrasts, as well as to develop concepts and tentative themes (Corbin \& Strauss, 2008). Triangulation of data sources allows the interpretation of data to make sense of the case and establish the trustworthiness of relationships between the three data sources (Stake, 1995).

The findings are not generalizable to all contexts. Merriam (2001) pointed out that generalization as traditionally defined is not the goal of qualitative research. The goal is rather to allow readers to "determine how closely their situations match the research situation and hence, whether findings can be 
transferred" (p. 211). The data collected and the interpretations of this research are meant foremost to clarify ideas for the researcher and to inform future research.

\section{Results}

An analysis of the narrative responses from the facilitator, and an analysis from the open-ended evaluations, were combined to reveal the manner in which the book discussion served as a professional-development approach, changing the belief systems of White in-service teachers surrounding their instruction delivered to CLD students. The themes of (1) localizing change and (2) a journey toward equity emerged.

\section{Localizing Change}

For purposes of this research, localizing change refers to the sentiment shared by the study participants with regard to their planned use of knowledge gained during the book study. The participants discussed change from a personal perspective, as well as from a professional perspective. The personal perspective involved their internal quest to change their understanding and comfort levels. Toward this end, they described seeking opportunities to interact with people of color as a means to 
"increase understanding and comfort." As they discussed localizing change, a greater focus on professional interaction between the teachers and administrators became evident. The participating educators reiterated the need for administrators to offer staff training on "cultural awareness" or "diversity." They reported a sense of empowerment related to questioning administration as a means of advocating for students of color. They viewed "working with other staff members" or "proposing staff development" as responsibilities.

The contextualization of change was clear with the participants of this study. They were able to articulate the steps involved in needed actions. For example, many spoke of creating a link between educators and community members through discussion groups. Many felt that the professional-development experience must be expanded to staff and administration. One participant expressed a desire "to be part of a team to bring a new understanding of working with diverse student populations." As the teachers discussed the personal and professional ways of applying learning gained from the book study, their views of White-identity theory emerged. They referred to the book study as providing them with a "sense of awakening," demonstrating the disintegration schema described by Helms (1999). The participating educators also described the need to seek opportunities to meet and develop relationships with people of color. This further illustrated their aim to eliminate racism and other forms of oppression on a micro level and within their school communities (Howard, 2006; Marshall, 2002; 
Ponterotto et al., 2006) by actively seeking authentic cross-cultural relationships (Diller \& Moule, 2005). The notion of localizing change may be more common for individuals entering or in the reconstructionist schema, in which participants may have come into some actualization of their social status and privilege as Whites in society (Helms, 1999).

\section{Journey Toward Equity}

As the teachers participating in this study reflected upon their experiences and the manner in which they were applying them, many discussed the "need to learn more" or the "desire to learn more about the topic." They realized that change was gradual and recognized the process as a journey, and therefore wanted more time to discuss more books. The teachers sought "concrete ideas to facilitate change" and wanted to "brainstorm more ideas for action." They expressed a commitment to their pilgrimage, acknowledging the positive change it would bring to their pedagogy and their perceptions of their current educational practice.

The teacher participants realized that it was necessary to step out of their "comfort zones" by engaging in "formal and informal interactions with students or people of color." This realization of change was evident among the study sample, and the participants desired to continue learning and examining their personal beliefs. The journey for some will allow for the critical realization of 
their social status and privilege as Whites within American society. The study discussions provided the participants with an academic understanding of racial classification (Sneed et al., 2006) and race as a system of advantage (Tatum, 1997). However, many of the teachers were unsure how to apply the knowledge gained, hence their expressions of "educating myself more" or "going to more diversity events in the community."

As the study participants continue their journeys of self-reflection, they will be challenged to explore their biases and prejudices surrounding race and students of color (D’Angelo \& Dixey, 2001; Ford \& Trotman, 2001). Teachers engaged in this journey may be entering or in the transformationist schema. Participants are acknowledging, confronting, and taking responsibility for the roles Whites play in perpetuating racism. As they assume this responsibility, they will also begin to seek a more critical understanding of the racist social construction of Whiteness, focus on personal change, and actively contribute toward positive change within their own cultural and ethnic groups.

\section{Implications and Recommendations for Teaching and Learning}

If the participants are seriously proactive about understanding themselves as racial beings, the book discussion will serve as a foundation for becoming racially and culturally conscious, culturally competent, and responsive within the classroom in 
order to bridge the cultural gap and transform students into enthusiastic learners (Grant \& Sleeter, 2007).

Considering the value placed on race in this country, it is critical for White teachers to examine what it means to be White within American society and to examine the manner in which this intersects with the personal and professional identities they present to CLD students within the school environment. These notions were highlighted as the study participants discussed increased involvement in conversations at the school and district levels regarding students of color. They discussed advocating for this student population by informing their peers of the knowledge they gained. It is likely that the participating teachers were not socially unconscious and unaware of the social implications of Whiteness, because participation in this study was a voluntary professionaldevelopment opportunity. However, such opportunities allow in-service teachers to confront racial and social issues without denying the social construction of race within a structured environment (Hardiman, 1982; Helms, 1999; Hill-Jackson, 2007; Ponterotto et al., 2006). The study findings revealed a critical need for open discussions about race, racial identity, and White racial identity and its implications for students.

If indeed the educational community is serious about empowering educators to be racially conscious and culturally competent in the classroom, the authors posit the need to support the professional development of in-service and 
preservice teachers. To this end, the authors make four recommendations. First, that teacher preparation programs integrate into their curriculum, coursework on White racial identity development along with other identity typologies. This requirement should employ ongoing critical conversations on race, beginning in the first year and culminating into student teaching. Second, that race and racial identity development conversation institutes be developed to train in-service educators as coaches. These coaches would be trained to establish race and racial identity development conversations in their respective school districts. These conversations would be similar to the voluntary study circles originating out of the Study Circles Resource Center (SCRC) in Columbus, Ohio, which meet on an ongoing basis to examine a societal issue. Third, that school districts hire teachers who show evidence within their portfolio or resume of coursework or professional development activities regarding race consciousness. Fourth, that more longitudinal research be conducted to evaluate the impact of professional development on teachers in their teaching and interaction with CLD students as it relates to race relations.

\section{Conclusion}

As a greater number of White teachers enter CLD classrooms, the need for increased training, professional development, and enhanced teacher ability to 
plan, develop, and implement culturally relevant, appropriate, and responsive practice will grow proportionately. Support must be ongoing throughout the preservice and in-service years for educators to acquire the necessary skills for success with CLD students. Periodic singular attempts, such as in-service professional-development courses, appear to only reinforce the prejudices and stereotypes frequently held by White teachers. The findings of this study demonstrate the need for this type of professional development in this area. The participating teachers indicated their desire to continue their learning. They are aware of positive changes manifesting within their classrooms and want their students to succeed. Educators must know how to meet the diverse needs of their students and apply appropriate pedagogical strategies.

A substantial body of research has described the identity development of White populations and its application within education contexts. Many investigators have focused on the critical need to prepare White teachers to successfully provide high-quality and equitable education for CLD students. The first step of this complex and ongoing process is to deconstruct and unlearn current ways of knowing. Integral to this effort is "unpacking the invisible knapsack of White privilege" (McIntosh, 1988, p. 12). Through reconstruction, teachers are able to move beyond the "grappling" process into an understanding of how their power and privilege prevent success for themselves as teachers and their CLD students as learners. Educators have typically acquired skills in 
questioning mainstream ways of knowing, living, and teaching and are able to apply these skills to their professional and personal identities. The journey may be uncomfortable; however, the process can indeed be conducted with honesty, empathy, advocacy, and positive action (Howard, 2006). Engaging in critical conversation through structured discussion will move classroom teachers through this process. Therefore, it is important that successful educators of CLD students who also know the process of identity transformation, scaffold other teachers through the process.

The aim of this study was to investigate whether a book discussion professional-development program, as a strategy, could place White in-service teachers on a path of becoming racially aware and learning to know themselves, their colleagues, and students of color in new and deeper ways (Howard, 2006). Novice teachers and many veteran educators have yet to reach this level of awareness. However, with an introduction to the ideas and concepts proposed in this study, the dialogue needed to prepare these teachers can be infused within the current paradigm of professional development to lead them to a path of discovering one's self as a racialized being. Howard advanced that transformationist teachers must abandon old ways of knowing, doing, and acting to embrace an inclusive, multicultural viewpoint within which teachers can collectively change the world-one student, one school, and one nation at a time. 


\section{References}

Banks, J. A. (2002). An introduction to multicultural education (3rd ed.). Needham Heights, MA: Allyn \& Bacon.

Cartledge, G., \& Kourea, L. (2008). Culturally responsive classrooms for culturally diverse students with and at risk for disabilities. Exceptional Children, 74(3), 351-371.

Chisholm, I. M. (1994). Preparing teachers for multicultural classrooms. Journal of Educational Issues of Language Minority Students, 14, 43-68.

D’Angelo, A., \& Dixey, B. (2001). Using multicultural resources for teachers to combat racial prejudice in the classroom. Early Childhood Education Journal, 29(2), 83-87.

Delpit, L. (2006). Other people's children: Cultural conflict in the classroom. New York, NY: New Press.

DiCaprio, P. (n.d.). Understanding diversity: A framework for understanding White racial identity development. Retrieved from http://www.pdfsearch.org/ru/janet\%20helms-pdf.html

Diller, J. V., \& Moule, J. (2005). Cultural competence: A primer for educators. Belmont, CA: Thomson Wadsworth.

Ford, D. Y., \& Trotman, M. (2001). Teachers of gifted students: Suggested multicultural characteristics and competencies. Roeper Review, 23(4), 23.

Gardiner, W. (2009). Developing a positive White identity. Diversity Factor, $17(1), 1-3$.

Gay, G. (2000). Culturally responsive teaching: Theory, research, \& practice. New York, NY: Teachers College Press.

- - - . (2003). The importance of multicultural education. Educational Leadership, 61(4), 30-35.

Gorski, P. (1998). Racial and gender identity development in White male multicultural educators and facilitators: Toward individual processes of self-development (Unpublished doctoral dissertation). University of Virginia, Charlottesville.

Grant, C. A., \& Sleeter, C. E. (2007). Turning on learning: Five approaches for multicultural teaching plans for race, class, gender. Hoboken, NJ: John Wiley and Sons.

Hardiman, R. (1982). White identity development: A process oriented model for describing the racial consciousness of White Americans (Unpublished doctoral dissertation). University of Massachusetts, Amhurst.

- - - . (2001). Reflections on White identity development theory. In C. L. Wijeyesinghe \& B. W. Jackson, III (Eds.), New perspectives on racial 
identity development: A theoretical and practical anthology (pp. 108128). New York, NY: New York University Press.

Helms, J. (1995). An update of Helms's White and people of color racial identity models. In J. G. Ponterotto, J. M. Casas, L. A. Suzuki, \& C. M. Alexander (Eds.), Handbook of multicultural counseling (pp. 181-198). Thousand Oaks, CA: Sage.

- - - (1999). Another meta-analysis of the White racial identity attitude scale's Cronbach alphas: Implications for validity. Measurement \& Evaluation in Counseling \& Development, 32(3), 122.

Hill-Jackson, V. (2007). Wrestling Whiteness: Three schemas of shifting multicultural perspectives among White pre-service teachers. Multicultural Perspectives, 9(2), 29-35. doi:10.1080/15 210960701386285

Howard, G. R. (2006). We can't teach what we don't know: White teachers, multiracial schools. New York, NY: Teachers College Press.

Kozol, J. (2005). The shame of a nation: The restoration of apartheid schooling in America. New York, NY: HarperCollins.

Ladson-Billings, G. (1994). The dream keepers: Successful teachers of African American children. San Francisco, CA: Jossey-Bass.

LaFleur, N., Rowe, W., \& Leach, M. (2002). Reconceptualizing White racial consciousness. Journal of Multicultural Counseling \& Development, $30(3), 148$.

Lawrence, S. M., \& Tatum, B. D. (1998). White racial identity and anti-racist education: A catalyst for change. In E. Lee, D. Menkart, \& M. OkazawaRey (Eds.), Beyond heroes and holidays: A practical guide to K-12 antiracist, multicultural education, and staff development (pp. 45-51). Washington, DC: Network of Educators on the Americas.

Manning, L. M. (2000, Winter). Understanding diversity, accepting others: Realities and directions. Educational Horizons, 78(2), 77-79. Retrieved from www.pilambda.org/ styles/pilambda/defiles/manning.pdf

Marshall, P. L. (2002). Racial identity and challenges of educating White youth for cultural diversity. Multicultural Perspectives, 4(3), 9-14.

McIntosh, P. (1988). White privilege and male privilege: A personal account of coming to see correspondences through work in women's studies (Working Paper No. 189). Wellesley, MA: Wellesley College Centre for Research on Women. Retrieved from http://www.eric.ed.gov/ERICWebPortal/search/detailmini.jsp?_nfpb=true\& _\&ERICExtSearch_SearchValue_0=ED335262\&ERICExtSearch_SearchT ype_0=no\&accno=ED335262 
Monroe, C. (2005). Understanding the discipline gap through a cultural lens: Implications for the education of African American students. Intercultural Education, 16(4), 317-330. doi:10. 1080/14675980500303795

Nieto, S. (2000). Affirming diversity: The sociopolitical context of multicultural education (3rd ed.). White Plains, NY: Longman.

Ponterotto, J. G. (1988). Racial/ethnic minority research in the journal of counseling psychology: A content analysis and methodological critique. Journal of Counseling Psychology, 35, 410-418. doi:10.1037/00220167.35.4.410

Ponterotto, J. G., Utsey, S. O., \& Pedersen, P. (2006). Preventing prejudice: A guide for counselors, educators, and parents. Thousand Oaks, CA: Sage.

Roman, L. G. (1993). White is a color! White defensiveness, postmodernism, and anti-racism pedagogy. In C. McCarty \& W. Crichlow (Eds.), Race, identity and representation in education (pp. 71-88). New York, NY: Routledge.

Rowe, W., Behrens, J. T., \& Leach, M. M. (1995). Racial/ethnic identity and racial consciousness: Looking back and looking forward. In J. G. Ponterotto, J. M. Casas, L. A. Suzuki, \& C. M. Alexander (Eds.), Handbook of multicultural counseling (pp. 218-235). Thousand Oaks, CA: Sage.

Rowe, W., Bennett, S. K., \& Atkinson, D. R. (1994). White racial identity models: A critique and alternative proposal. Counseling Psychologist, 22, 129-146. doi:10.1177/0011000094221009

Sabnani, H. B., Ponterotto, J. G., \& Borodovsky, L. G. (1991). White racial identity development and cross-cultural training. Counseling Psychologist, 19, 76-102.

Sadker, D. M., Sadker, M. P., \& Zittleman, K. R. (2008). Teachers, schools, and society, annotated instructor's edition (8th ed.). Boston, MA: McGrawHill.

Sleeter, C. E. (1993). How White teachers construct race. In C. McCarthy \& W. Crichlow (Eds.), Race, identity, and representation in education (pp. 157171). New York, NY: Routledge.

- - - . (2001). Preparing teachers for culturally diverse schools: Research and the overwhelming presence of Whiteness. Journal of Teacher Education, 52(2). doi: 10.1177/0022487101052002002

Sneed, J., Schwartz, S., \& Cross, J. (2006). A multicultural critique of identity status theory and research: A call for integration. Identity, 6(1), 61-84.

Solomon, R. P., Portelli, J. P., Daniel, B.-J., \& Campbell, A. (2005). The discourse of denial: How White teacher candidates construct race, racism and White privilege. Race, Ethnicity \& Education, 8(2), 147-169. 
Stalvey, L. (1989). The education of a WASP. Madison, WI: University of Wisconsin Press.

Sue, D. W., Carter, R. T., Casas, J. M., Fouad, N. A., Ivey, A. E., Jensen, M., . . Vazquez-Nutall, E. (1998). Multicultural counseling competencies: Individual, professional and organizational development. Thousand Oaks, CA: Sage.

Tatum, B. (1992). Talking about race, learning about racism: The application of racial identity development in the classroom. Harvard Educational Review, 62(1), 1-24.

- - . (1997). Why are all the Black kids sitting together in the cafeteria? New York, NY: Basic Books. 